\author{
Marcin Popiel \\ Uniwersytet Pedagogiczny \\ im. Komisji Edukacji Narodowej \\ w Krakowie
}

\title{
Dark tourism jako element innowacyjności biur podróży
}

Dlaczego śmierć fascynuje ludzi? Odpowiedzi na to pytanie można by mnożyć. Na przestrzeni wieków śmierć znajdowała się w centrum zainteresowań człowieka, który traktował ją jako zdarzenie naturalne lub - temat zakazany. Przykładowo walki gladiatorów w czasach romańskich, jak i publiczne egzekucje w średniowieczu były zgodne z normami ówczesnych społeczeństw. Z kolei obecnie śmierć jest dla wielu osób tematem tabu. Mimo to wiele miejsc, które połączone są w sposób bezpośredni tudzież pośredni ze śmiercią, stało się w ostatnich latach atrakcjami turystycznymi. Mowa tu nie tylko o pomnikach wojennych, polach bitewnych, obozach koncentracyjnych, które przyciągają turystów ze względów religijnych czy patriotycznych, ale także o miejscach klęsk żywiołowych i nieszczęśliwych wypadków. Liczba wyżej wymienionych atrakcji wciąż rośnie, czy to w sposób celowy, czy przypadkowy. Następują też próby waloryzacji miejsc związanych z celebracją zdarzeń historycznych o znaczeniu symbolicznym (np. związanych z bitwą warszawską). Po tragedii bliźniaczych wież World Trade Center w Nowym Jorku (2001 rok) pojawiała się tam niezliczona liczba odwiedzających. Podobna sytuacja ma miejsce $\mathrm{z}$ innymi miejscami tragedii, klęsk na całym świecie. Czy zatem zainteresowanie sferą nieszczęścia, sferą śmierci wzrasta, czy po prostu rynek turystyczny wykorzystuje ten trend i może obecnie więcej zaoferować (np. pakiety turystyczne, obejmujące podróżowanie w miejsca, które dokumentują i upamiętniają śmierć)? W literaturze angielskiej taka turystyka określana jest mianem dark tourism ('ciemna, mroczna turystyka') lub thanatourism (Tanaś 2006). Wiele biur podróży wprowadza ten szczególny i innowacyjny rodzaj zwiedzania świata do swojej oferty, szukając w nim szansy na wzrost konkurencyjności swojej firmy, a w krytycznych wypadkach - nawet na pozostanie na rynku. Wprowadzanie innowacyjnych elementów przez touroperatorów wynika poniekąd z charakteru rynku turystycznego, który przeobraża się bardzo szybko wraz z rozwojem świata i zmieniającymi się ludzkimi potrzebami (motywami podróży).

\section{Rozwój turystyki}

Zainteresowanie turystyką, podróżowaniem jest znane ludzkości od wieków. W obecnych czasach ta forma spędzania wolnego czasu nadal się rozwija, o czym mogą świadczyć statystyki dotyczące liczby turystów biorących udział w turystyce przyjazdowej. W 2009 roku podróżowało $880 \mathrm{mln}$ osób, które wydały w ramach turystyki 610 mld $€$, natomiast w 2010 roku liczba podróżujących wyniosła $940 \mathrm{mln}$ osób, które wydały 693 mld $€$ (World Tourism Organization 2011) (ryc. 1). 
Ryc. 1. Wielkość ruchu w turystyce oraz wydatki turystów w latach 1990-2010

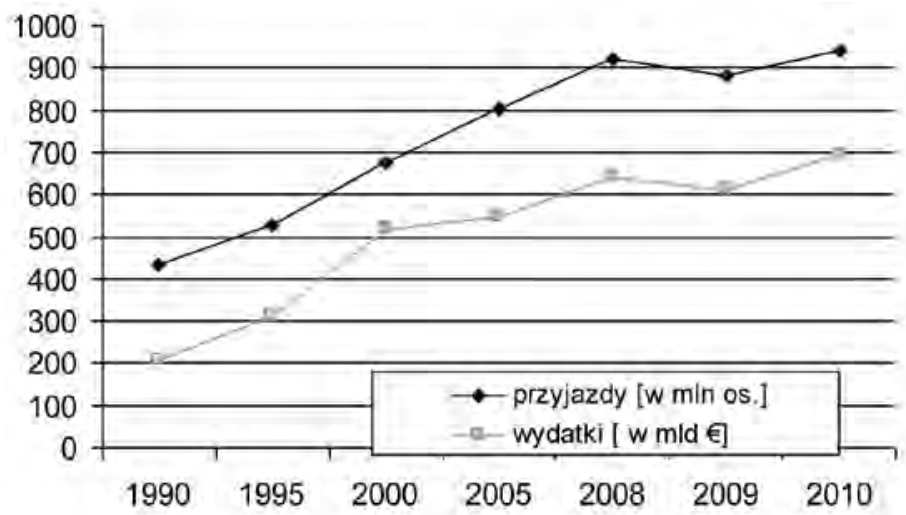

Źródło: opracowanie własne na podstawie: World Tourism Organization 2011.

Pomimo tak wielkiej liczby przejazdów tylko połowa osób podróżujących w 2010 roku wyjechała w celach wypoczynkowych, rekreacyjnych czy wakacyjnych ${ }^{1}$. Reszta to wyjazdy osobiste lub służbowe. Pod koniec XX wieku zaczęły zachodzić poważne zmiany w turystyce związane z zewnętrznymi uwarunkowaniami aktu podróżowania, preferencjami turystów, ich zachowaniami. W relacji rynek turystyczny - klient ważne jest, by touroperatorzy (którzy są przedstawicielami pierwszego z wyżej wymienionych elementów) potrafili zawczasu rozpoznać te zmiany oraz wynikające z nich nowe trendy w turystyce. Dzięki szybkiej reakcji będą mogli ukierunkować swe strategie marketingowe, produkty i usługi na innowacje (Kruczek 2009).

Według prognoz dla sektora turystycznego na lata 1997-2020, na zmiany w turystyce wpłynie wiele czynników. Jednym z ważniejszych jest czynnik związany z odczuciami klientów, mianowicie odstąpienie od gospodarki usług na rzecz doświadczenia. Ma to swoje odzwierciedlenie w zmianie nastawienia turysty. Priorytetem nie jest już jakość świadczonych usług, wygoda, bezpieczeństwo, lecz chęć zdobycia doświadczenia, wyjątkowych doznań poprzez działanie (Kowalczyk 2002). Mowa tu o nowym modelu turystyki, który określany jest mianem „3 x E” (ang. Entertainment, Excitement, Education). Najważniejszymi założeniami tej formy są: rozrywka, ruch, ekscytacja, rozwój emocjonalny oraz zdobywanie wiedzy. Wypierana jest tym samym tradycyjna, komercyjna turystyka „3 x S” (ang. Sea, Sun, Sand), która charakteryzuje się małą aktywnością ruchową, przeważnie wypoczynkiem w nadmorskich kurortach oraz rozwojem turystyki masowej, która niesie za sobą negatywne skutki społeczno-gospodarcze (Kurek 2007). Model „3 x E” oddaje główne założenia geografii turyzmu, którymi zajmuje się od lat wielu badaczy. Według nich o wyborze turystycznej destynacji nie decyduje tylko jeden element, lecz system (krajobraz obszarów atrakcyjnych turystycznie), będący zbiorem elementów i sprzężeń między nimi (Krzymowska-Kostrowicka 1980).

\section{Innowacje i marketing w turystyce}

Innowacja może się odnosić do rożnych płaszczyzn, wymiarów funkcjonowania firm. Istnieje różnica $\mathrm{w}$ procesach unowocześniania przedsiębiorstw przemysłowych firm z sektora turystycznego, stąd wiele opracowań naukowo-badawczych, podejmujących tematykę innowacyjności w turystyce.

\footnotetext{
${ }^{1}$ A. Kowalczyk wśród celów podróży turystycznych wyróżnia między innymi cel: wypoczynkowy, poznawczy, handlowy, kongresowy, pielgrzymkowy. Zob. Kowalczyk 2002, s.151.
} 
Innowacje są kluczowym czynnikiem funkcjonowania przedsiębiorstw, pozwalającym na ich szybki rozwój. „Zdarza się, że przedsiębiorstwa wprowadzające innowacje unikają niebezpieczeństw wynikających z działań konkurencji i potrafią wykorzystać pojawiające się szanse rynkowe w taki sposób, który gwarantuje uzyskanie przewagi konkurencyjnej" (Rejmann 2007, s. 221). Efektywność innowacji zależy w dużej mierze od przepływu aktualnej informacji i wykorzystania jej oraz dotychczasowej wiedzy w odpowiednim czasie. Ważny jest szereg powiązań, relacji między współpracownikami na rynku, od których zależy opracowanie, wdrożenie, a w rezultacie - sprzedaż innowacji (Kochmańska 2011).

W turystyce można wydzielić pięć rodzajów innowacji. Dotyczą one: produktów i usług, szeroko pojętych procesów, zarządzania, marketingu oraz instytucjonalności (Szarecki 2010) (ryc. 2).

Ryc. 2. Innowacje w turystyce

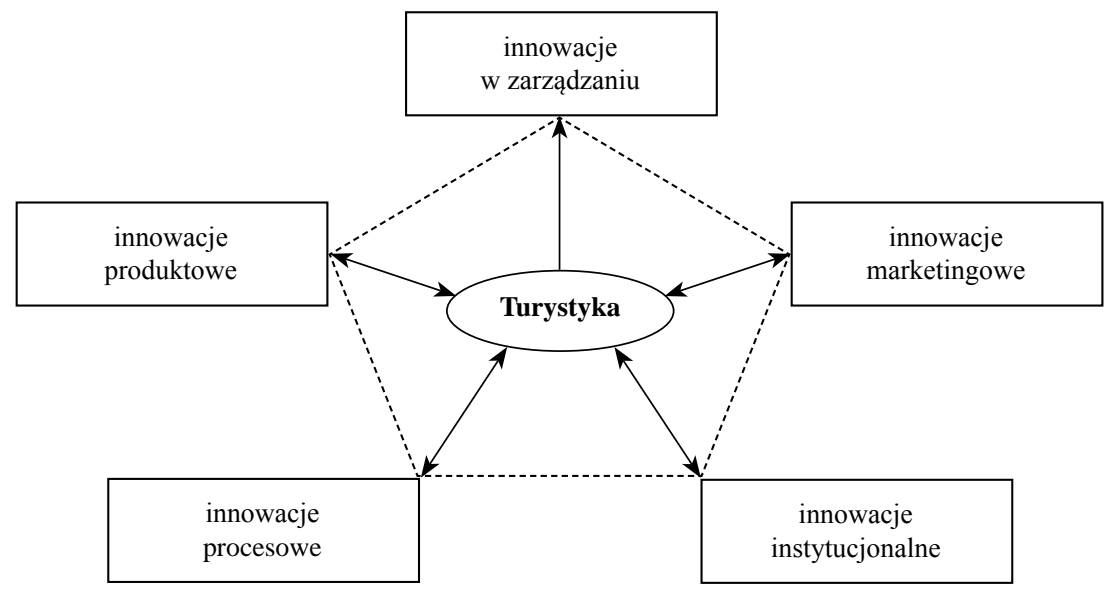

Źródło: Szarecki 2010.

Klasycznymi innowacjami są zmiany w gamie produktów, usług świadczonych na rzecz turysty. Rozumiane jest przez to wprowadzenie ofert, które mogą być nowe dla danego przedsiębiorstwa turystycznego, jak i dla całego sektora turystycznego.

Marketing w turystyce to działanie mające na celu obserwację i przewidywania zmian na rynku - zmian zachowań, oczekiwań i potrzeb turystów, którzy w myśl strategii przedsiębiorczości są najważniejsi. Zmiany często wynikają z czynników zewnętrznych, więc ważne jest, by systematycznie badać rynek turystyczny, a tym samym zachowania turystów, by być świadomie zorientowanym - w danym momencie wahań na rynku - na masowe lub niszowe potrzeby i oczekiwania turystów (segmentacja rynku). Wyróżnia się cztery typy marketingu w zależności od rozmiaru segmentu (Kurek 2007):

- marketing masowy - zorientowany na szeroki i mało zróżnicowany rynek,

- marketing selektywny - zorientowany na jednorodną, ale dość dużą grupę turystów,

- marketing niszowy - zorientowany na wąski segment rynku, często na indywidualne potrzeby,

- marketing typu one to one - zorientowany na mocno rozwinięte indywidualne oferty. 


\section{Atrakcyjność turystyczna i innowacje z tym związane}

Atrakcyjność turystyczna to złożone pojęcie. O atrakcyjności danego regionu, miejsca itd. decydują cechy przyrodnicze, jak również pozaprzyrodnicze. Są one elementami obiektywnymi, ale na atrakcyjność wpływa także percepcja, odbiór i ocena turystów (Kurek 2007). Z przytoczonej powyżej reguły można wnioskować, iż istnieją problemy z obiektywnym procesem waloryzacji zasobów turystycznych ${ }^{2}$, gdyż ich ocena przez turystów jest związana $z$ indywidualnymi odczuciami, zwłaszcza gdy mowa o zasobach pozaprzyrodniczych. Wpływ na ich decyzję ma wiele czynników, między innymi aspekt psychologiczno-emocjonalny, społeczno-kulturowy, ekonomiczny itd., co tym bardziej uniemożliwia obiektywną waloryzację. Założenia te przedstawia percepcyjno-behawioralny model ruchu turystycznego (Kowalczyk 2002) (ryc. 3).

Ryc. 3. Percepcyjno-behawioralny model ruchu turystycznego

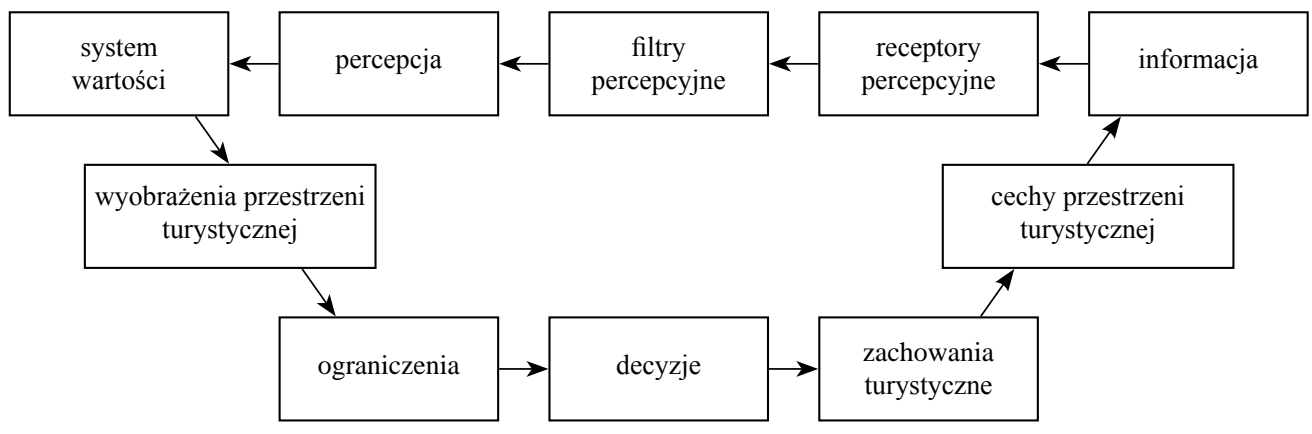

Źródło: Kowalczyk 2002, s. 106.

Powyższy model wskazuje na relacje pomiędzy turystami a otaczającym ich środowiskiem. Wynika z niego, że decyzje i zachowania turystów związane są ze zmodyfikowanymi wyobrażeniami, które są odbierane przez człowieka poprzez zmysły, emocje oraz indywidualny system wartości (Kowalczyk 2002).

Na podstawie przedstawionych powyżej różnic i nieścisłości w procesie waloryzacji zasobów turystycznych, a tym samym w ocenie ewentualnej atrakcyjności turystycznej przez różnych turystów, rozwijają się nowe formy turystyki. Jedną z form turystyki poznawczej jest turystyka kulturowa. Nie ma jednoznacznej definicji oddającej założenia tej formy spędzania wolnego czasu. W wąskim znaczeniu wiąże się ona z zainteresowaniem zabytkami lub pamiątkami historycznymi zebranymi obecnie w muzeach. W szerszym zaś znaczeniu - bliższym obecnym założeniom - jest to podróżowanie w celu zdobycia wiedzy o świecie, innych ludziach, ich sposobie życia, zaspokajanie ciekowości zobaczenia ludzi w ich naturalnym środowisku, poznanie ich sposobów radzenia sobie z przeciwnościami losu, aż w końcu - doznania unikatowych emocji poprzez doświadczenie i działanie (Kurek 2007). Jak widać, turystyka kulturowa jest wielowymiarowa, nieokreślona w sposób jednoznaczny do dnia dzisiejszego, dzięki czemu pozostawia otwarte drzwi dla nowych form turystyki, które poniekąd wiążą się z powyższymi założeniami.

\footnotetext{
${ }^{2}$ Zasoby turystyczne są to elementy środowiska przyrodniczego oraz pozaprzyrodniczego, które mają możliwość stania się walorem turystycznym po odkryciu przez turystów i uzyskaniu ich pozytywnej oceny.
} 
Dark tourism wpisuje się właśnie w turystykę kulturową. Jak już była mowa, w literaturze określenie dark tourism zastępowane jest również synonimem tanatoturystyka (ang. Thanatourism). Słowo to składa się de facto z dwóch członów: thanatos (według greckiej mitologii Tanatos to uosobienie śmierci, przedstawiane jako śpiący młodzieniec, trzymający $\mathrm{w}$ dłoni zgaszoną, skierowaną w dół pochodnię) oraz tourism (z ang. 'turystyka') (Tanaś 2006). Oba te określenia wynikają z faktu, że tego typu turystyka wykorzystuje mroczne elementy: zdarzenia związane ze śmiercią, z katastrofami i nieszczęściem. Temat ten podjęło kilku autorów. Badacze Lennon i Foley w 2000 roku, w książce pt. Dark Tourism: The Attraction of Death and Disaster, określili dark tourism jako podróżowanie w miejsca świata dotknięte katastrofami, przykładowo na pola bitewne, miejsca tragicznych wydarzeń oraz miejsca związane z ludobójstwem (np. obozy koncentracyjne). P.R. Stone w 2009 roku określił ten rodzaj turystyki jako „akt podróży w celu zwiedzenia zabytków związanych ze śmiercią, nędzą i koszmarem”, natomiast według słownika wydawnictwa Macmillan pojęcie to oznacza podróżowanie specjalnie w miejsca tragedii lub katastrof (Molokáčová, Molokáč 2011).

Pierwszymi wyprawami związanymi z udaniem się w miejsca śmierci, mogił, cmentarzy były pielgrzymki. Jest to pierwowzór turystyki związanej z kultem śmierci. Największy rozkwit pielgrzymek miał miejsce w średniowiecznej Europie, stąd również właśnie ten czas uznaje się za początek tanatoturystyki. Według mentalności społeczeństwa tamtych czasów, żyło się po to, by osiągnąć zbawienie, a śmierć była jedną z możliwości. Dzięki takiemu podejściu i tej prostej idei śmierć stawała się bliższa ludziom (Tanaś 2006). Poprzez myślenie, iż jest to koniec życia ziemskiego, lecz jednocześnie początek życia wiecznego, człowiek starał się wpływać na swoje pośmiertne losy poprzez szereg dobrych zachowań w codziennym życiu.

Rozpowszechnienie tanatopsii (czyli rozmyślań nad śmiercią) nastąpiło w dużej mierze przez kościół chrześcijański, który wykorzystywał motyw śmierci zarówno w malarstwie, rzeźbie, ogólnie pojętej sztuce, kulturze, jak również w słowie pisanym i mówionym. Tanatopsja była zatem kluczowym elementem pielgrzymek do miejsc, w których ludzie mogli oddawać cześć męczennikom, przyszłym świętym, modlić się do nich, oglądać ich relikwie. Najczęściej były nimi skrawki ubrań, osobiste przedmioty czy nawet części ciała. Kult męczenników uwarunkowany był głównie ich moralnością, religijnością, jak również charakterem tortur, uwięzienia, egzekucji, których doświadczyli. Udział w pielgrzymce zatem - poprzez obcowanie z motywem śmierci, tragicznymi historiami ludzi - miał duchowo przygotowywać ludzi tak, by nie byli zaskoczeni śmiercią (Tanaś 2006).

Obecnie nieodłącznym elementem wielu wycieczek, organizowanych przez touroperatorów, jest zwiedzanie miejsc, które były świadkami ludzkiej śmierci, cierpienia, katastrof. Przykładem mogą być: Koloseum w Rzymie, gdzie odbywały się historyczne walki gladiatorów, rzymskie miasto Pompeje, które zniszczone zostało przez erupcję wulkanu w 79 roku n.e., liczne pola bitewne, place średniowiecznych miast, gdzie odbywały się publiczne egzekucje oraz cmentarze, gdzie pochowane są znane osoby czy zasłużeni bohaterowie wojenni. Przykładem kolejnym - tym razem z naszego otoczenia - jest obóz koncentracyjny Auschwitz-Birkenau w Oświęcimiu, który przyciąga rokrocznie ogromną liczbę zwiedzających. Nikogo nie dziwią takie elementy w ofercie turystycznej biur podróży, gdzie czas, historia, przeszłość kreują powyższe miejsca na atrakcje turystyczne przy jednoczesnym założeniu większego dystansu i szacunku dla nich.

Obecnie pojęcie ciemnej turystyki powoli się zmienia, co jest związane ze wspominaną ewolucją turystyki z ,3 x S” w ,3 x E”. Żyjemy w dobie sensacji, gdzie ciekawość ludzka kreuje wielkość popytu i podaży usług turystycznych. Rynek turystyczny związany jest również z mass mediami. Człowiek, włączając telewizję, radio czy czytając codzienną prasę, otrzymuje 
często informacje z ostatniej chwili, co świadczy o tym, że w drodze rozwoju komunikacji w obecnym świecie nastąpił wzrost szybkości przekazu informacji. Zauważalna jest również tendencja mediów do eksponowania wydarzeń i zjawisk związanych z założeniami ciemnej turystyki. Za początek masowego przedstawiania tragedii w mediach uważa się zatonięcie Titanica w 1912 roku. Od tego momentu media chętnie skupiają się na raportowaniu tragedii ze świata, gdyż przyciągają one szersze grona odbiorców przed radioodbiorniki, ekrany telewizorów itd. W ten sposób media mogą przyciągać i popychać ludzi w stronę omawianego rodzaju turystyki; przez przekaz pisemny czy słowny media docierają do podświadomości turystów, obrazując im miejsca tragedii oraz nieświadomie czyniąc z nich atrakcje (Yuill 2003).

Wpływ mediów na rozwój turystyki śmierci, jako mediatora między potencjalnymi turystami a rynkiem turystycznym reprezentowanym przez touroperatorów, przedstawia poniższy model współzależności (ryc. 4).

Ryc. 4. Media jako element rynku turystycznego pośredniczący w rozwoju ciemnej turystyki

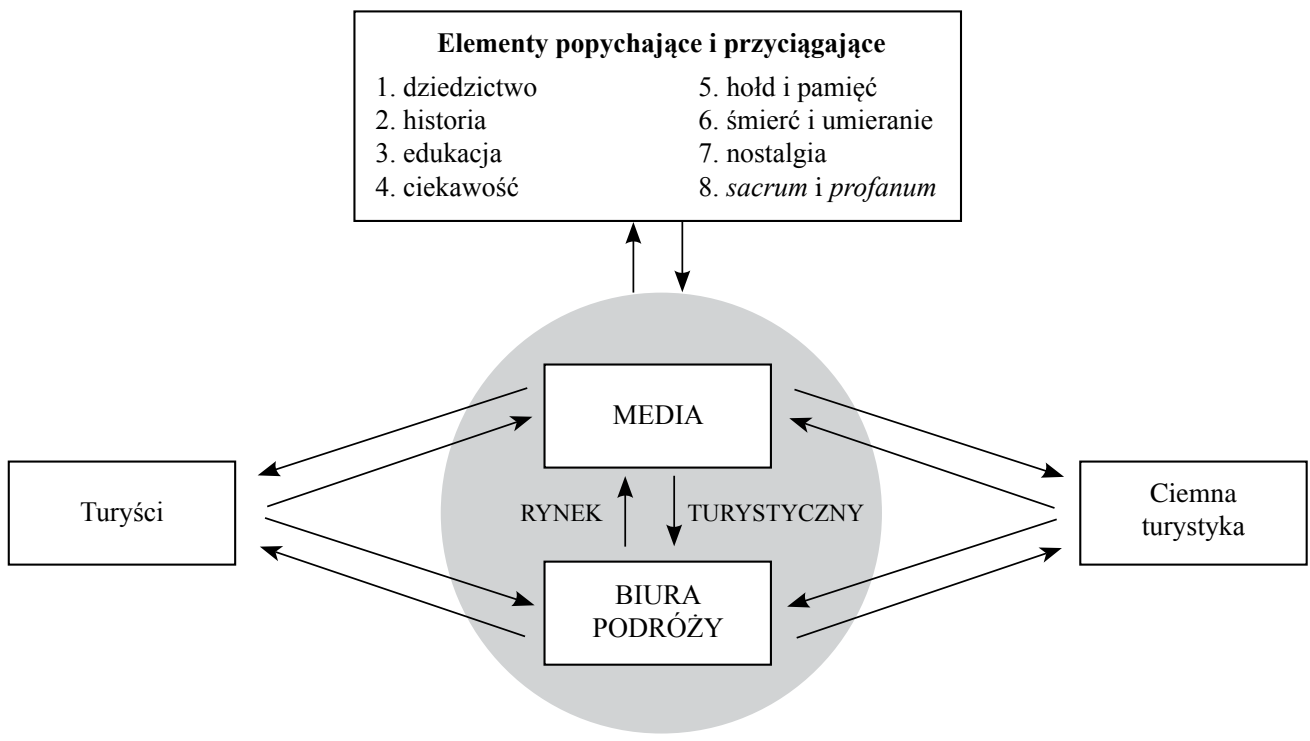

Źródło: opracowanie własne na podstawie: Yuill 2003.

Najpopularniejszym współczesnym przykładem rozwoju przyczynowo-skutkowego pomiędzy wydarzeniem (tragedią) nagłośnionym przez media a ofertą biur podróży ukierunkowaną na zaspokojenie potrzeb zainteresowanych nim turystów wydaje się być atak terrorystyczny z 11 września 2001 roku w Nowym Jorku. Dowodem na to, iż smutek może podwoić liczbę turystów, są statystyki porównujące liczbę odwiedzin tarasu widokowego na World Trade Center sprzed ataku z liczbą odwiedzin strefy Ground Zero w 2002 roku po ataku. Bliźniacze wieże przyciągały rocznie ok. 1,8 mln zwiedzających (2001 rok), natomiast po katastrofie w przeciągu pierwszych 12 miesięcy - liczba ta wzrosła dwukrotnie (3,6 mln turystów) (Griffiths b.d.). Wzrost zainteresowania zobaczeniem strefy Ground Zero po ataku wywołał natychmiastową lawinę zorganizowanych ofert turystycznych, umożliwiających zaspokojenie tej potrzeby. Zaczęto rozwijać marketing mający na celu przyciągnięcie turystów. W Nowym Jorku wiele biur podróży oferuje wycieczki specjalnie w miejsce tragedii. Są warianty z przewodnikiem lub bez (wówczas z audioprzewodnikiem). Powstała również ogromna liczba stron 
internetowych na temat zwiedzania Ground Zero. Cała ta koniunktura wpływa na rozwój biur podróży, oferujących ten innowacyjny produkt. Poza touroperatorami, którzy oferują tę usługę dla korzyści materialnych, istnieje również wiele organizacji zrzeszających osoby bezpośrednio dotknięte tragedią. Organizacje te również oferują odpłatne wycieczki do strefy Ground Zero, lecz cały zysk ze sprzedaży biletów oddawany jest osobom, których bliscy zginęli pod gruzami World Trade Center (zob. http://www.tributewtc.org).

W tym miejscu należy wspomnieć, że wraz z rosnącą „,atrakcyjnością” turystyczną strefy Grodnu Zero (i nie tylko - prawidłowość ta dotyczy też innych miejsc) nasila się zjawisko określane jako tourist trap (z ang. 'pułapka turystyczna'). Polega ono na podejmowaniu działań, których celem jest wyciągnięcie od turystów pieniędzy (Kruczek 2009). Najbliższe otoczenie miejsca tragedii - w ciągu już kilku miesięcy po ataku - zajęli straganiarze, którzy sprzedają pamiątki, na przykład czapki, koszulki, nagrania filmowe, książki i wiele innych.

Kolejnym przykładem zza oceanu świadczącym o tym, że biura podróży mogą się rozwijać dzięki katastrofie, jest miasto Nowy Orlean. Ludzkie cierpienie oraz ogromne zniszczenia stały się tam atrakcją turystyczną po doświadczeniu tego miasta przez huragan Katrina. Spowodował on śmierć 1400 osób oraz zalanie w wyniku powodzi $80 \%$ miasta. Woda uszkodziła lub całkowicie zniszczyła 95\% miasta - blisko 350 domów (City of New Orleans Communications Department 2008). Pomimo tej tragedii bardzo dużo osób pragnie zobaczyć to znane im z ekranów telewizorów miejsce. W odpowiedzi na to zapotrzebowanie powstały biura podróży oferujące specjalne wycieczki śladami zniszczeń huraganu. Jedno z nich - biuro Tours By Isabelle - na swojej stronie internetowej informuje wytłuszczonym drukiem, iż nie jest to zwykła wycieczka po Nowym Orleanie, lecz w $90 \%$ dotyczy ona wpływu huraganu Katrina na miasto i miejscową ludność. Koszt takiej podróży to 65 \$ od osoby. Po zapoznaniu się ze sprawozdaniami osób, które odbyły tę wycieczkę, można wnioskować, iż zainteresowanie jest spore (zob. http://www.toursbyisabelle.com). Inne lokalne biuro podróży - Dixie Tours - oferuje specjalną wycieczkę w region najbardziej zniszczony przez huragan Katrina. Koszt wyprawy to $49 \$$ od osoby (lub $42 \$$ przy zamówieniu przez Internet). Oferta ta jest kolejnym przykładem innowacyjności usługowej i marketingowej, związanej ze zmianą zainteresowań turystów, ich podejściem do podróżowania, a co za tym idzie - rozwojem ciemnej turystyki (zob. http://www.dixietoursneworleans.com). Trzecim przykładowym biurem, które po katastrofie wprowadziło wycieczkę śladami huraganu jako odzew na zapotrzebowanie rynku turystycznego, związanego z przeżyciem nieodwołalnie autentycznego doświadczenia oraz poznaniem sposobu radzenia sobie miejscowej ludności ze skutkami tragedii, jest biuro Gray Line z Nowego Orleanu. Koszt organizowanej przez nie wycieczki to 38 \$. W swojej ofercie biuro posiada więcej wypraw związanych $\mathrm{z}$ ciemną turystyką, jak choćby zwiedzanie muzeum II wojny światowej, cmentarzy i innych (zob. http://www.graylineneworleans.com).

Wraz z upływem czasu i rozwojem biur podróży, które oferują zorganizowane wycieczki po Nowym Orleanie, wzrasta liczba turystów (w 2006 roku liczba osób odwiedzających to miasto spadła o 35\%) (New Orleans Convention and Visitors Bureau 2011).

Przedstawione powyżej przykłady odnoszą się do Stanów Zjednoczonych, lecz marketing prowadzony przez touroperatorów - w tych przypadkach - jest marketingiem masowym, gdyż tragedie, które są magnesem przyciągającym turystów, zostały przedstawione $\mathrm{w}$ mediach na całym świecie. Wszyscy ludzie uczestniczyli poniekąd w tych wydarzeniach na skutek przekazów medialnych. Istnieje również marketing selektywny biur podróży, który odnosi się do jednorodnych, dużych grup (Holloway, Robinson 1997). W odniesienie do ciemnej turystyki wiąże się on z lokalnymi, narodowymi tragediami, nieszczęściami. Wiele krajów ma takie miejsca, wydarzenia, które rozwijają turystykę śmierci, lecz najlepiej zaprezentować przykład z polskiego środowiska. 
Najważniejszym wydarzeniem ostatnich lat, które wywarło wpływ na turystykę, była katastrofa polskiego samolotu pod Smoleńskiem 10 kwietnia 2010 roku. W jej wyniku zginęło 96 osób, w tym Prezydent Rzeczypospolitej Polskiej Lech Kaczyński z małżonką Marią Kaczyńską. Po tym wypadku wiele biur podróży w Polsce wprowadziło - w ramach marketingu i innowacyjności, polegających na analizowaniu rynku i potrzeb turystów - wycieczkę w miejsce katastrofy. Jak pokazuje przykład łódzkiego biura podroży Wilejka, w ciągu miesiąca po katastrofie touroperator wysłał 60 osób pociągiem oraz 100 osób autokarami na miejsce tragedii. Tych 160 turystów w ciągu miesiąca to ośmiokrotnie więcej niż liczba turystów, których biuro posłało do Katynia w całym 2009 roku (Stangret 2010). Powstała również specjalna strona internetowa, która oferuje loty i zorganizowane wycieczki autokarowe na miejsce katastrofy. Znajduje się na niej także lista touroperatorów w Polsce, którzy na potrzeby zmieniających się motywów wyjazdów turystów wprowadzili do swej oferty wycieczki do Smoleńska (zob. http://wycieczkidosmolenska.pl). Największe zainteresowanie ofertami miało miejsce w ciągu kilku miesięcy po wypadku. Wyjeżdżały wówczas zarówno osoby indywidualne, jak i zorganizowane grupy, nierzadko szkolne.

W przypadku powyższej katastrofy - w dłuższym odstępie czasu po tragedii, kiedy ruch turystyczny zdecydowanie ustał - ciężko mówić o klasycznym zjawisku dark tourism, gdyż większość wypraw do Katynia i Smoleńska zawsze miała charakter patriotyczny, natomiast wycieczka do lasu, gdzie nastąpiła tragedia, jest jedynie ich elementem, ,atrakcją turystyczną”. Przykład ten miał jednak ukazać nagłe wykorzystanie przez touroperatorów trendu, popytu rynkowego i wprowadzenie innowacyjnego elementu do ofert - pakietów turystycznych - które dzięki temu cieszyły się bardzo dużym zainteresowaniem.

Ciemna turystyka jest silnie związana z dziedzictwem kulturowym i tragedie są jej nieodłączną częścią. Jest to szczególny rodzaj ruchu turystycznego, który nie musi trafiać do wszystkich, ale odgrywa znaczącą rolę w łączeniu przeszłości z teraźniejszością, powodując nierzadko osobiste, świeże emocje, jak również szerokie dyskusje na temat ciemnej strony historii oraz ludzkości. Najważniejszy w tego typu podróżach jest motyw edukacyjny i emocjonalny. Ludzie są zafascynowani śmiercią częściowo ze względu na fakt, iż jest to temat tabu, który zazwyczaj powoduje milczenie i stwarza dystans. Organizowanie wyjazdów ciemnej turystyki pozwala im na obserwację tematów związanych ze śmiercią, cierpieniem z bezpiecznej odległości. Zaspokaja to ciekawość, sprzyja kontemplacji oraz daje poczucie dbania o własne dziedzictwo.

Na podstawie wyżej opisanego działania biur podroży pozostaje pytanie, czy rola przedsiębiorczości biur podróży w ramach edukacji turystów, na przykładzie powstawania powyższych, innowacyjnych, ofert jest pomysłem bardzo dobrym, czy może niemoralnym? Czy w ogóle śmierć może być ,,atrakcją turystyczną”? Z jednej strony wycieczki te mają uczyć, pokazywać świat bez tajemnic, uwrażliwiać na ludzki los, często również dawać okazję do bezinteresownej pomocy finansowej dla poszkodowanych czy ich rodzin. Wiele osób uważa jednak, iż takie zwiedzanie jest nieetyczne. Często w pogoni za sensacją, aktualną tragedią, katastrofą brakuje dystansu i szacunku do tego, co się stało, a przecież za każdym wydarzeniem stoją ludzie, ich emocje, nieszczęścia, które w tym momencie są sprowadzane do rangi lokalnej atrakcji. Warto zatem zastanowić się nad sensownością oraz pozytywną tudzież negatywną stroną powstawania takich ofert. 


\section{Literatura}

1. City of New Orleans Communications Department, 2008, Twenty important facts on the recovery of New Orleans post - Katrina and on the subsequent flooding; New Orlean, City of New Orleans Communications Department, http://www.neworleansonline.com/pr/releases/releases/20\%20Important\%20Facts\%20About\%20New\%20Orleans.pdf (dostęp: 3.04.2008).

2. Griffiths K., b.d., Ground Zero \& the phenomena of 'Dark Tourism', Pilot Film \& Television Productions Ltd., http://www.pilot.co.uk/destination_guide/north-america/new-york/ground_zero.php (dostęp: 16.09.2011).

3. Holloway Ch. J., Robinson Ch., 1997, Marketing w turystyce, Polskie Wydawnictwo Ekonomiczne, Warszawa.

4. Kochmańska M., 2011, Zarządzanie innowacjami w matych $i$ średnich przedsiębiorstwach $w$ warunkach globalizacji [w:] Przedsiębiorczość w warunkach globalizacji, Z. Zioło, T. Rachwał (red.), „Przedsiębiorczość - Edukacja”, nr 7, wydawnictwo Nowa Era, Zakład Przedsiębiorczości i Gospodarki Przestrzennej Instytutu Geografii Uniwersytetu Pedagogicznego im. Komisji Edukacji Narodowej w Krakowie, Warszawa - Kraków, s. 90-102.

5. Kowalczyk A., 2002, Geografia turyzmu, Wydawnictwo Naukowe PWN, Warszawa.

6. Kruczek Z., 2009, Między atrakcją a pulapka turystyczna. Dylematy turystyki kulturowej XXI wieku [w:] Kultura i turystyka, razem, ale jak, A. Stasiak (red.), Wydawnictwo WSTH, Łódź, s. 71-80.

7. Krzymowska-Kostrowicka A., 1980, Terytorialny system rekreacyjny, analiza strategii, Zakład Narodowy im. Ossolińskich, Wrocław.

8. Kurek W. (red.), 2007, Turystyka, Wydawnictwo Naukowe PWN, Warszawa.

9. Molokáčová L., Molokáč S., 2011, New Phenomenon-Dark Tourism, Acta Geoturistica, tom 2, nr 1, s. $1-7$.

10. New Orleans Convention and Visitors Bureau, 2011, New Orleans' Tourism Industry Post Katrina Recovery Milestones 2005-2011, New Orlean, New Orleans Convention and Visitors Bureau, http://www.neworleansonline.com/pr/releases/releases/Sixth\%20Anniversary\%20Katrina\%20Tourism\%20Milestones.pdf (dostęp: sierpień 2011).

11. Rejman K., 2007, Wpływ innowacyjności na efektywność wspótczesnych przedsiębiorstw [w:] Rola przedsiębiorczości w aktywizacji gospodarczej, Z. Zioło, T. Rachwał (red.), „Przedsiębiorczość - Edukacja”, nr 3, wydawnictwo Nowa Era, Zakład Przedsiębiorczości i Gospodarki Przestrzennej Akademii Pedagogicznej im. Komisji Edukacji Narodowej w Krakowie, Warszawa - Kraków, s. $220-224$.

12. Stangret M., 2010, Smoleńsk travel, czyli Polacy na szlaku katastrofy, „Ogólnopolski Dziennik Metro", nr 1824, http://www.emetro.pl/emetro/1,85651,7843393,Smolensk_travel_czyli_Polacy_na_ szlaku_katastrofy.html (dostęp: 4.05.2010).

13. Szarecki M., 2010, Rodzaje innowacji w turystyce, http://ww.naukaigospodarka.pl/index.php?optio$\mathrm{n}=$ com_content\&view=article\&id $=257 \% 3$ Arodzaje-innowacji-w-turystyce \&catid $=39 \% 3$ Aartykuly \&Itemid=108\&lang=pl (dostęp: 28.06.2010).

14. Tanaś S., 2006, Tanatoturystyka - kontrowersyjne oblicze turystyki kulturowej; „Peregrinus Cracoviensis", z. 17.

15. World Tourism Organization, 2011, Tourism Highlights 2011 Edition, Madrid, UNWTO Publications, http://mkt.unwto.org/sites/all/files/docpdf/unwtohighlights11enhr_1.pdf (dostęp: 30.04.2011).

16. Yuill S.M., 2003, Dark Tourism: Understanding visitor motivation at sites of death and disaster, A thesis submitted to the office of Graduate Studies, Texas A\&M University, Texas, http://repository. tamu.edu/bitstream/handle/1969.1/89/?sequence=1 (dostęp: 30.09.2004). 


\section{Dark tourism as an innovating element of travel agencies}

Travelling, both in a history of the world and or even more in the present times, is far from commonly accepted ways to do leisure activities. Tourism has evolved from the traditional "3 x S" (Sea, Sun, Sand) to "3 x E" (Entertainment, Excitement, Education). Desire to enjoy new experiences, feel unique emotions and take certain actions, it is what prevails now. A relatively new form of tourism - dark tourism, provides such an opportunity. Traveling through trails of disasters, accidents, visiting places associated with calamities and death are the best examples of such tourism.

The tourism market, which is represented by, among others, the mass media, provides all sorts of information to potential tourists. Natural curiosity and desire to explore the world drives people to see a phenomenon, which is in the centre of attention of everyone. Some travel agencies are introducing innovative tourism products associated with it and by means of that they become more competitive on the tourist market.

Yet the question remains whether such trips are a great idea or perhaps they are immoral. On one hand they educate and sensitize people to the plight of others, but on the other hand the human misery is becoming a sort of tourist attraction, therefore one should consider the existence and creation of such innovative offers. 